UDK 783.9

\author{
Sandra Graham
}

Department of Music, University of California (Davis)

Oddelek za glasbo, Univerza v Kaliforniji (Davis)

\title{
What's the Score? Interpreting Transcriptions of the Fisk Jubilee Spirituals
}

\section{Partitura? Interpretacija transkripcij duhovnih pesmi zbora »Fisk Jubilee Singers«}

Ključne besede: transkripcija, historična etnomuzikologija, črnske duhovne pesmi, Fisk Jubilee Singers

IZVLEČEK

Theodor Sewatdove transkribcije rabijo kot prikaz njegovega šolanja (in domnev v glasbi v okviru tega šolanja) ter kot strateško izhodišče za oblikovanje miselnega koncepta glede duhovnih pesmi, s tem da so nakazane možnosti uporabe citiranih partitur kot vira koristnega etnografskega znanja.
Keywords: transcription, historical ethnomusicology, Negro spirituals, Fisk Jubilee Singers

Abstract

I consider Theodore Seward's transcriptions of the Fisk Jubilee Singers' spirituals as a representation of his training (and the assumptions about music inherent in that training), and as a strategy for creating an ideology about the spirituals, demonstrating ways in which these scores might be repositories of useful ethnographic knowledge.

In early 1872, a slim volume of 24 Negro spirituals was published. Titled Jubilee Songs, as Sung by the Jubilee Singers, it contained transcriptions of spirituals sung by the Jubilee Singers, a group of black students from Fisk University in Nashville, Tennessee, one of the earliest black schools to be founded after the Civil War. At the time of publication the Jubilee Singers were several months into a concert tour of the northern United States in order to raise money for their destitute institution. Those concerts, and the songbooks, initiated the widespread emergence of black spirituals into the public sphere. Later in 1872, a second volume of transcriptions was published, expanded from 24 to 61 songs. Beginning in 1873, these 61 songs were appended to a book-length narrative about the singers. At least 35 editions of the scores were published between 1872 and 1903 (including British publications as well as translations 
into Dutch and German), bringing some 125 spirituals to an international, largely white music-buying audience. These scores - some of which have been reprinted in modern editions and others of which are readily found in libraries and used bookstores today - are still widely consulted. ${ }^{1}$

As is well known by now, the Jubilee Singers sang folk spirituals that were arranged for concert performance by their white director, George White, for the most part in a homophonic texture that recalled European hymns. White's simple arrangements reflected both his limited musical education - he was self-taught - and the repertory he grew up with, in which church hymns figured prominently. White himself never wrote down the spirituals. It seems that he learned the spirituals from his singers orally, arranged them to his liking, and then taught his arrangements to the singers by rote.

For reasons that are lost to history, the task of transcribing the spirituals fell to someone with no connection to Fisk University: Theodore Seward (1835-1902). From a public relations perspective, Seward had a desirable pedigree: He was the greatgrandson of Colonel John Seward, an American Revolutionary War leader, and second cousin to William Henry Seward, who had been Abraham Lincoln's Secretary of State (1861-1869). He studied music with Lowell Mason, George Frederick Root, and Thomas Hastings, who were among the most popular American composers of the day. He travelled in Europe, he was editor in the 1860s of both the Musical Pioneer and the Musical Gazette, and when he finally settled down in New Jersey with his family in 1870, he worked as music director of the public schools in East Orange, as well as organist at two churches, and published a variety of song collections designed to musically educate and morally edify. His church credentials made him attractive to the American Missionary Association, which founded Fisk University, and his public profile as an editor gave him a certain prestige among those who would purchase Jubilee Songs. The fact remains, however, that despite this rich musical background, he had no previous knowledge of African American culture or folk music generally. Given this, what can these transcriptions of a southern black folk music by a Northern white church musician with no previous knowledge of spirituals possibly tell us about the music?

In a foreword to Jubilee Songs, American Missionary Association official E. M. Cravath writes that the spirituals "were taken down from [the Singers'] lips by Mr. White, who has had charge of their musical training, and the music was reduced to writing by Theo. F. Seward." Seward, in his preface to the songs, expands on this, assuring the public that "the music herein is entirely correct. It was taken down from the singing of the band, during repeated interviews held for the purpose, and no line or phrase was introduced that did not receive full indorsement from the singers." ${ }^{2}$ Seward's assertion of accuracy opened the door for criticism by knowledgeable contempora-

One reprint edition is J.B.T. Marsh, The Jubilee Singers and Their Songs (1892; Dover Publications, 2003). For a list of original editions see Dena J. Epstein, "The Story of the Jubilee Singers: An Introduction to Its Bibliographic History," in Josephine Wright and Samuel A. Floyd (eds.), New Perspectives on Music: Essays in Honor of Eileen Southern, 151-162 (Warren, Mich.: Harmonie Park Press, 1992); and Sandra Graham, "The Fisk Jubilee Singers and the Concert Spiritual: The Beginnings of an American Tradition," ch. 5 and App. C (Ph.D. dissertation, New York University, 2001).

2 [Theodore F. Seward], Jubilee Songs: As Sung by the Jubilee Singers of Fisk University, preface signed by Theodore F. Seward (New York: Biglow \& Main, 1872). 
neous music critics, including one of the Jubilee singers, as well as by modern scholars such as Dena Epstein, all of whom found the transcriptions inaccurate, sometimes grossly so. ${ }^{3}$

That there were mistakes is not surprising, on many grounds. For example, Seward was an adherent of John Curwen's Tonic-Sol-Fa system, a solmization method popular in Britain, especially in Sunday schools, public schools, and amateur choral societies. Musically illiterate students who learned to sight-read using Tonic-Sol-Fa usually did not bother to learn standard notation. The method stresses tonality, as opposed to a "fixed-do" system. Students first mastered the members of the tonic triad and then progressed to the dominant triad. Rhythm was represented by a system of barlines, colons, and commas that marked strong and weak beats. Silence was indicated not by symbols but by a vacant space that was visually proportionate to the length of silence. Clearly, this method was inadequate for representing melodic and rhythmic nuance. Furthermore, it encouraged adherents to conceive of every song as being in a major or minor key, even if the melody consisted of only four or five different pitches. Seward was a zealous advocate of Tonic-Sol-Fa in America, and he used it at least some of the time to transcribe the initial singing of the Jubilee Singers, which he later translated into conventional notation. ${ }^{4}$ It is important to keep in mind this invisible translation process when interpreting the reliability of Seward's transcriptions.

Not only was Seward inexperienced with folk music, but he had no great interest in ethnography. Unlike the editors of the first volume of spirituals to be published, Slave Songs of the United States (1867), ${ }^{5}$ who were trying to preserve these songs through a descriptive score, Seward's goal was to create a prescriptive score that would allow audiences to sing these spirituals at home. Whereas the scores in Slave Songs were frequently accompanied by a description of performance context and the circumstances under which the song was collected, Seward's transcriptions - for the most part - were left to stand on their own.

Even granting the existence of inaccuracies and lack of background information about the individual songs, however, I believe that Seward's transcriptions reveal important clues about the music and its sound. Seward was representative of the Jubilee Singers' white audiences in that he had no extensive experience with African Americans or African American music, he was Protestant, and he supported the emancipation of blacks in America. Also, like most white listeners, his musical frame of reference for the spirituals derived from Western European common practice. This is especially salient in his comments on form in the preface to Jubilee Songs. For example, Seward implies in his preface that the spirituals unfold for the most part in balanced phrases (usually of two or four measures). However, he also writes, "we see few cases

\footnotetext{
For a summary of these criticisms, see Graham, "Fisk Singers," ch. 5, esp. 164-170. The singer who criticized Seward's transcriptions is Thomas Rutling; I explore his objections in From Slave Song to America's Music: The Popularization of Negro Spirituals (University of Illinois Press, in preparation).

Although it is not certain he did this for the 1872 publications of Jubilee Songs, Fisk singer Ella Sheppard notes in her diary that he used this technique in 1875; Andrew Ward, Dark Midnight When I Rise: The Story of the Jubilee Singers Who Introduced the World to the Music of Black America (NewYork: Straus, Farrar, \& Giroux, 2000), 281.

William Francis Allen; Charles Pickard Ware; and Lucy McKim Garrison (eds.), Slave Songs of the United States (1867; reprint, New York: Dover, 1995).
} 
of what theorists call mis-form," which implies that some formal anomalies do occur. Although he fails to provide examples, an examination of the transcriptions yields some possible candidates, one of them being "Oh! Sinner Man."

The chorus begins with a 5-measure phrase complemented by a 4-measure phrase (Figure 1). Since the verse consists of balanced phrases, the asymmetry of the chorus is striking. One could argue that Seward simply made a mistake in his transcription although if it was a mistake, it was never corrected. Lack of "correction" is not necessarily significant; as I will discuss later, even glaring errors were rarely corrected in later editions. However, asymmetrical forms are common in both black and white American folk music, and the fact that several examples of asymmetry exist in the transcriptions suggests that White's so-called European arrangements of the spirituals did not entirely erase indigenous practice.

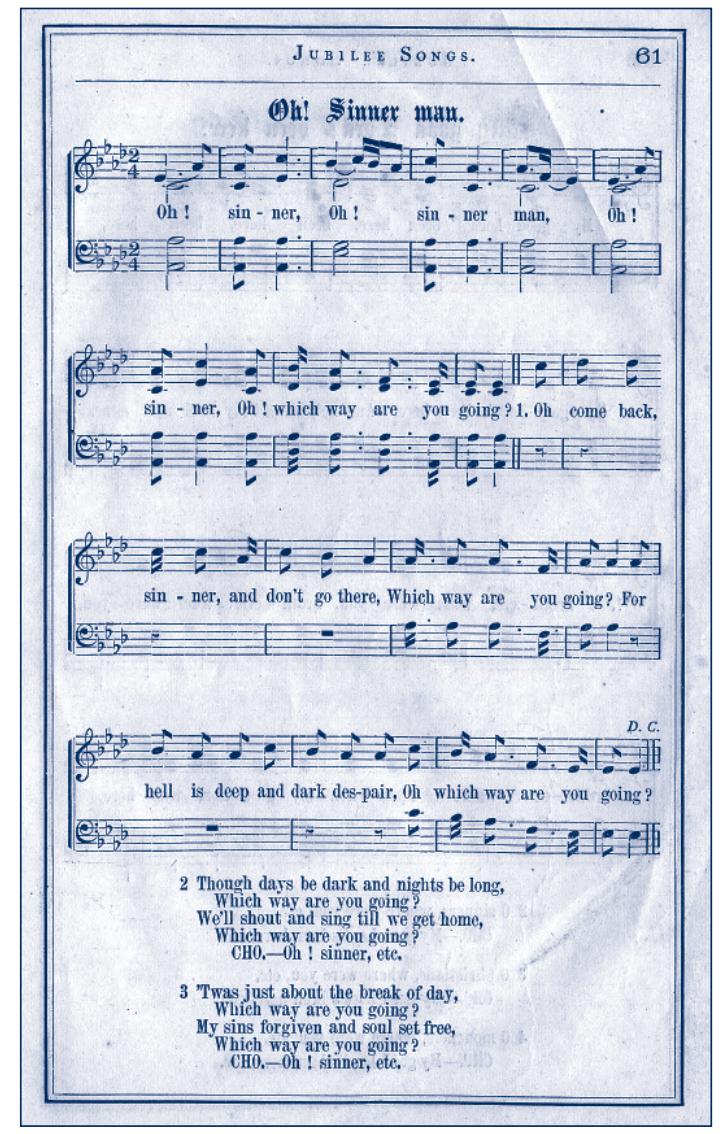

Figure 1. Asymmetrical phrase structure in "Oh! Sinner Man": The first 9 measures comprise the chorus. Source: Theodore Seward, Jubilee Songs: Complete (New York: Biglow \& Main, 1872). Special Collections, University of California Library, Davis. 
Another example of folk retentions involves rhythm. Seward notes in his preface that spirituals are differentiated from conventional melodies by their rhythm, "which is often complicated, and sometimes strikingly original." For example, he writes in a footnote to the spiritual "Room Enough": "The peculiar accent here makes the words sound thus: "rooma nough," so that the first syllable of "enough" aurally becomes the second syllable of "room" (Figure 2). In spoken American English, the stress in this phrase would be "room enough"; as set to this melody, however, the stress is instead "roome-nough." Although examples of rhythms that contradict spoken stress are in the minority in the published transcriptions, their presence, and the fact that Seward calls attention to them, is noteworthy. Perhaps such rhythms were more common in these spirituals but were not remembered by the Singers, or were changed by George White, or were incorrectly transcribed by Seward. If the spirituals were originally sung in a dialect or creole, perhaps the rhythms fit the original speech patterns but made less sense when the words were translated into standard English. Whatever the explanation, Seward's commentary on such rhythms in the transcriptions reveals one way in which white listeners found the spirituals to be different, and exotic.

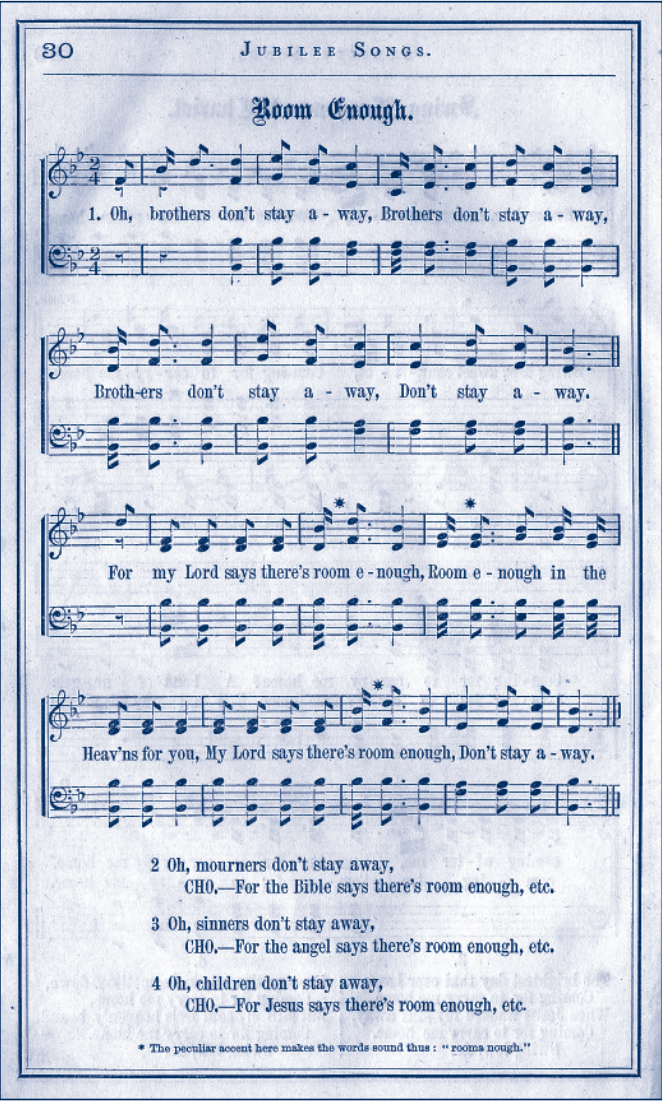

Figure 2. "Room Enough": Notated rhythm contradicts spoken stress at asterisk. Source: Theodore Seward, Jubilee Songs: Complete (New York: Biglow \& Main, 1872). Special Collections, University of California Library, Davis. 
Seward drew attention in his transcriptions to another aspect of the spirituals: the "run-on" or continuous flow of certain cadences between verse and chorus. On the first page of the transcriptions, he notes: "It will be observed that in most of these songs the first strain is of the nature of a chorus or refrain, which is to be sung after each verse. The return to this chorus should be made without breaking the time." Despite this general instruction, Seward felt the need to underscore it in footnotes to several spirituals. For example, in "Didn't My Lord Deliver Daniel," the final cadence of the first verse ends on an eighth note. Seward footnotes this cadence, writing, "Go on without pause, leaving out two beats of the measure." The term "leaving out" implies that one would "normally" expect a pause between the verse and chorus, and indeed if this were a Protestant hymn, the cadence would likely consist of a dotted half note (Figure 3). In this case, not only does the chorus flow continuously from the verse, but representing this requires that the transcriber "rob" the measure of two beats. To Seward's credit, he did not attempt to "fix" this anomaly but simply noted the characteristic performance practice.

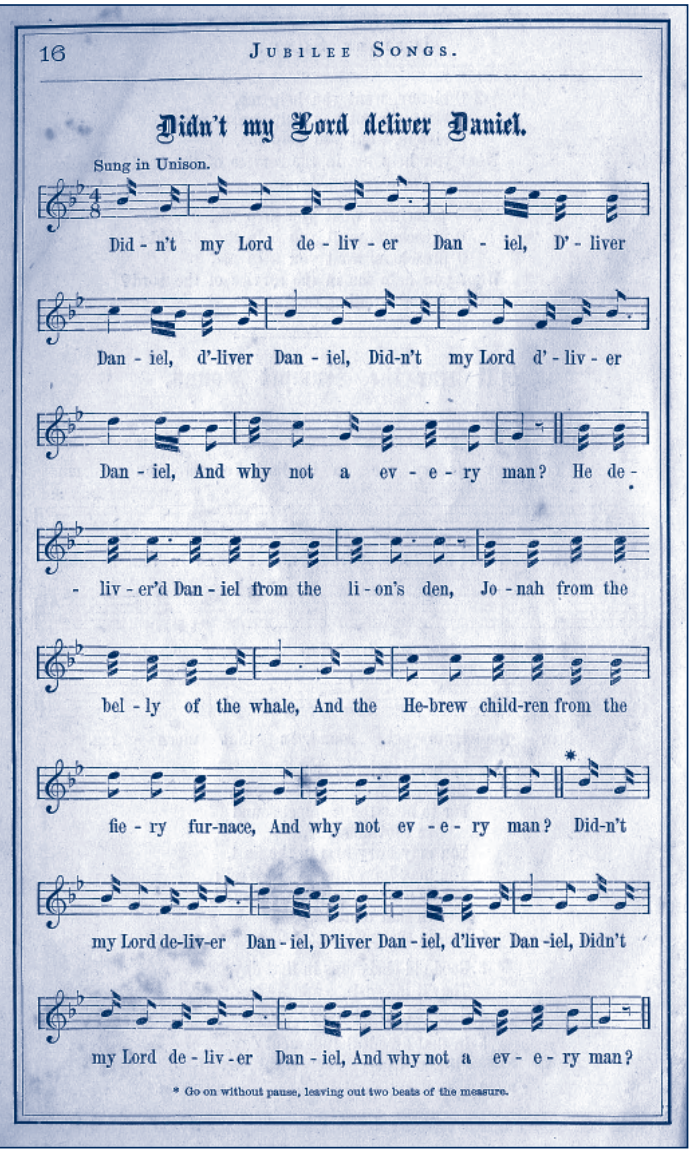

Figure 3. Excerpt from "Didn't $M y$ Lord Deliver Daniel": unusual cadence at end of 6th line. Source: Theodore Seward, Jubilee Songs: Complete (New York: Biglow \& Main, 1872). Special Collections, University of California Library, Davis. 
References to the so-called European-style harmonizations of the spirituals have become commonplace. Of the 61 spirituals published in the 1872 publications, 22 (about one third) were unharmonized and several more (e.g., "Roll, Jordan, Roll," "Gwine to Ride up in the Chariot," "Go Down, Moses") were mostly unharmonized (with only a few measures of harmonization). We know from the transcriptions themselves as well as from newspaper reviews that the unharmonized spirituals were sung either in group unison or as solos. The remaining spirituals were harmonized in two or four parts. Newspaper reviews also confirm that the spirituals were unaccompanied in performance.

A close examination of the part writing reveals that European hymns were less of a stylistic model for the jubilee songs than it appears at first glance. White's harmonizations show an overwhelming reliance on root-position chords; an almost exclusive reliance on tonic, dominant, and subdominant triads; occasional doses of open fifths and parallel voice leading; ${ }^{6}$ and an almost complete absence of passing tones. A prime example is "Steal Away," which became the Jubilee Singers' signature spiritual (Figure 4). The part writing and melodic outline relentlessly reiterate the tonic, and yet this spiritual was an immediate favorite with audiences and was used to open almost every concert. The harmonic monotony in the arrangement suggests that the power of this song lay elsewhere, and this is confirmed in firsthand accounts from reviews, diaries, and letters, which describe and extol expressive devices such as absolute rhythmic synchronicity, perfect enunciation, and dramatic dynamic changes that underscore the message of the lyrics (the song begins with a barely audible pianissimo and swells to a grand forte). For example:

The basis of his [George White's] tone coloring was one note, the very first of every concert, the opening whisper of "Steal away to Jesus." Exquisite in quality, full of the deepest feeling, so exceedingly soft that it could hardly be heard, yet because of its absolute purity carrying to the farthest part of any large hall, it commanded the attention of every audience. As the tone floated out a little louder, clearer, rose to the tremendous crescendo of "My Lord Calls Me," and diminished again into exquisite pianissimo sweetness, the most critical enemy was conquered. ${ }^{7}$

As this description and others make clear, it was not the "song itself" as depicted in the notation but the performance practice that accounted for the song's expressive power.

\footnotetext{
See, e.g., "A Little More Faith in Jesus" (parallel octaves in the bass and soprano/alto parts), plus "Old Ship of Zion" and "Judgment Day Is Rolling Round" (open fifths).

Mary Spence, "A Character Sketch of George L. White," Fisk University News 2, no. 5 (1911), 4.
} 


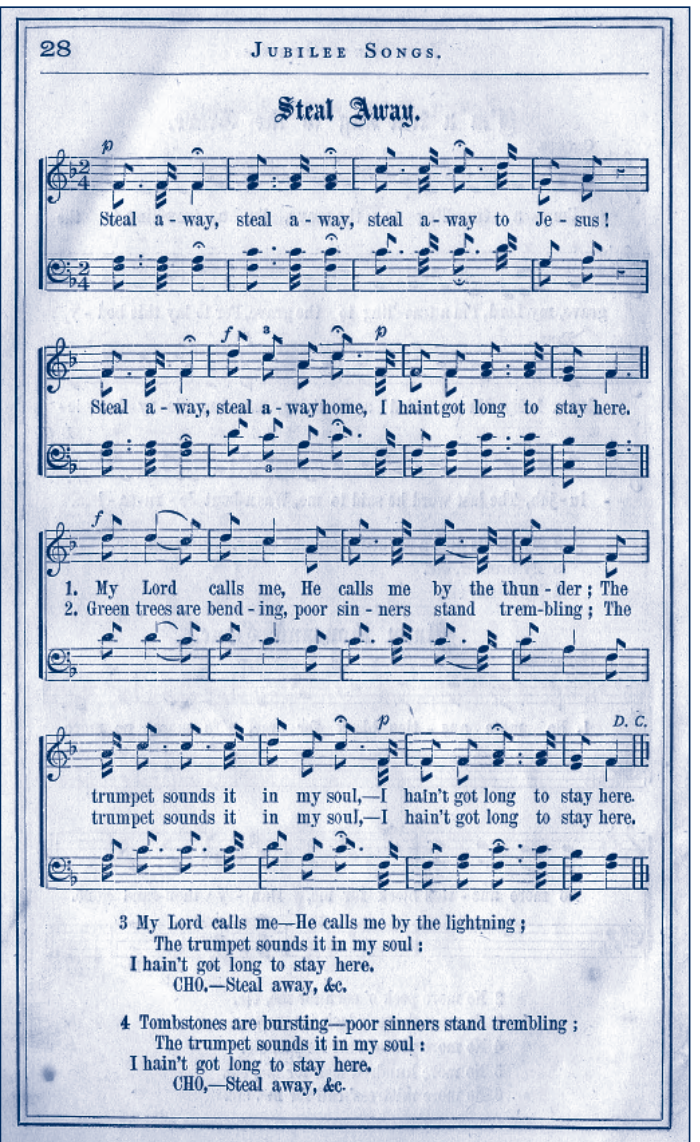

Figure 4. "Steal Away." Source: Theodore Seward, Jubilee Songs: Complete (New York: Biglow \& Main, 1872). Special Collections, University of California Library, Davis.

The existence of so many editions of jubilee songs invites comparison to see what changes were made in the notation from one to the next. Most changes were innocuous, involving revisions of typography, layout, and lyrics (e.g., the insertion of a double barline to mark the end of a section, or addition of labels like "verse" or "chorus"), whereas more important musical errors, such as a missing or incorrect time signature, remained uncorrected. ${ }^{8}$

In editions from 1875 onward, however, there are some more substantial revisions in notation that contrast with the cosmetic changes made in earlier editions. The most significant of these occur in "Roll, Jordan, Roll." Figure 5a shows the original arrangement, and Figure 5b shows the revision first printed in Marsh's Story of the Jubilee Singers (1875), which remained in all future editions. ${ }^{9}$ The differences are striking:

$8 \quad$ For example, "Give Me Jesus" has no time signature. Published in Seward's first Jubilee Songs (1872), it remained the only spiritual without a time signature throughout later editions. "Judgment Day Is Rolling Round," also published in Seward's first Jubilee Songs, has an erroneous time signature of $2 / 4$ instead of $4 / 4$ or $2 / 2$; this also was not subsequently corrected. "I Ain't Going to Die No More," published in Seward's second publication of Jubilee Songs (1872), with a time signature of 2/4, contains an error of note duration in measure 10. For more examples, see Graham, "Fisk Jubilee Singers," 192-195. [J.B.T. Marsh, ed.] The Story of the Jubilee Singers; With Their Songs, 2nd ed. (London: Hodder \& Stoughton, 1875). 


\begin{tabular}{|l|l|}
\hline Seward (1872a) & Marsh (1875) \\
\hline The chorus begins in unison. & $\begin{array}{l}\text { The sopranos and altos begin, followed by the } \\
\text { basses (and tenors?) in the second measure, } \\
\text { singing a slide from Eb to Db. }\end{array}$ \\
\hline There is a fermata in m. 2. & $\begin{array}{l}\text { The slide makes the fermata in m. } 2 \text { impractical; } \\
\text { it is deleted. }\end{array}$ \\
\hline $\begin{array}{l}\text { In the first measure of the verse, } \\
\text { the text setting is syllabic. }\end{array}$ & $\begin{array}{l}\text { In the first measure of the verse, a three-note } \\
\text { melisma is written on the word "ought." }\end{array}$ \\
\hline Verse 7 begins "Oh, children." & Verse 7 begins "Oh, sisters." \\
\hline
\end{tabular}

The changes in Marsh's 1875 edition are all characteristic of folk performances of spirituals (as opposed to the more refined concert practice): imprecise pitches (slides), melismas, and changeable texts. Although I have found no evidence to explain why

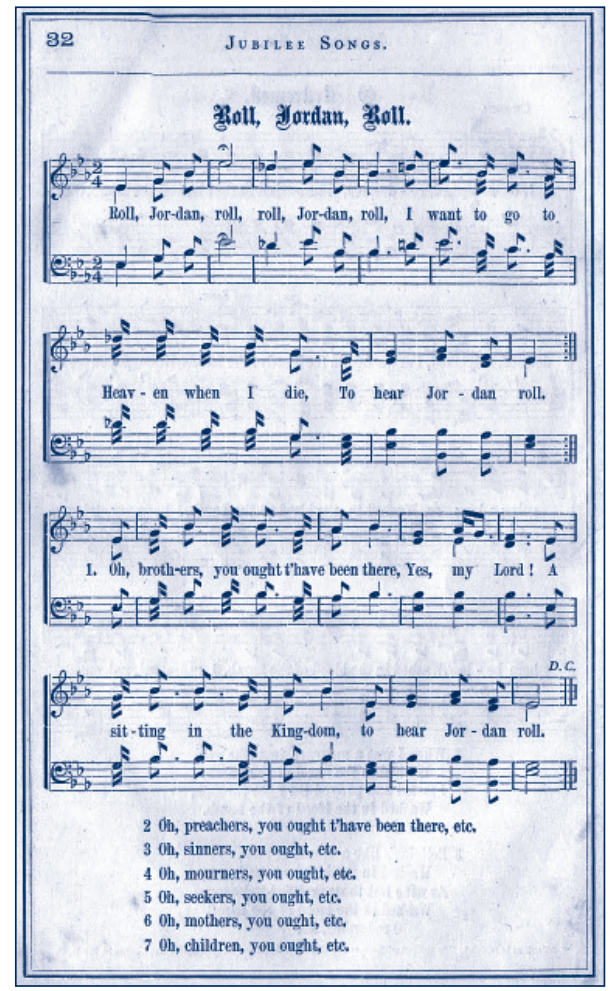

Figure 5a. Earlier version of "Roll, Jordan, Roll." Source: Theodore Seward, Jubilee Songs: Complete (New York: Biglow \& Main, 1872). Special Collections, University of California Library, Davis.

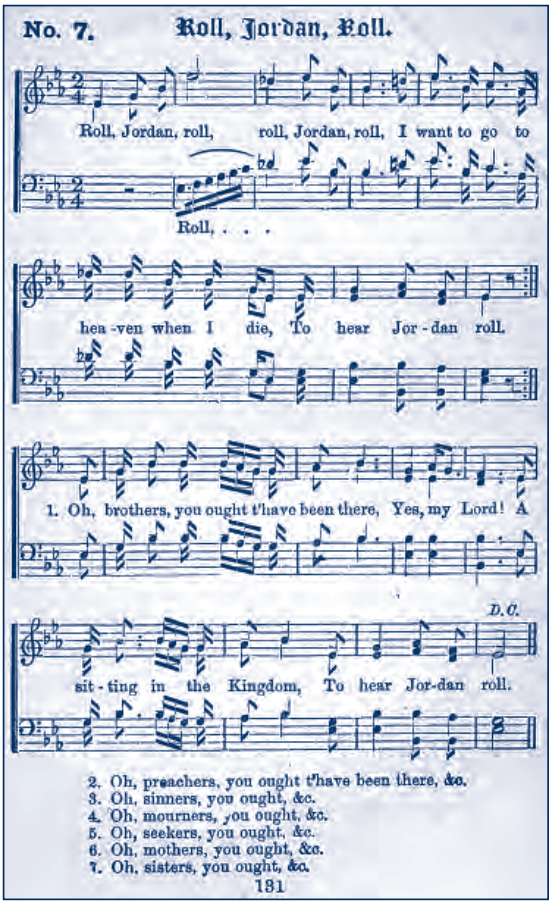

Figure 5b. Revised transcription of "Roll, Jordan, Roll." Source: The revised version first appeared in 1875; this score was taken from J.B.T. Marsh, The Story of the Jubilee Singers; with their songs, rev. ed. (Boston: Houghton, Mifflin E Co., 1880). Personal copy. 
these changes were made, one logical hypothesis is that new singers entering the troupe brought with them different versions and performance styles that White and Seward found more appealing than the original arrangement. In the case of "Roll, Jordan, Roll" the changes - the roll, in particular - could have been instigated by bass singer Frederick Loudin, who joined the troupe in the fall of 1874 . Loudin had a big voice and a commanding stage presence, and he quickly became one of the star performers. Newspaper reviewers frequently commented on the pictorial aspect of the bass roll. The coincidence of Loudin's arrival and the musical revision suggests cause and effect, but no other transcription was revised so significantly. Why would Loudin have had an effect on this one spiritual but not on others? It is possible that he did introduce changes to other spirituals, but that Seward revised only the transcription to "Roll, Jordan, Roll" because of its popularity. For example, a newspaper report about the performance of another spiritual, "I'm a-Rolling," describes Loudin's rolling bass line and arpeggio, but there is no evidence of these in any of the transcriptions.

Another hypothesis is that these changes were made to more accurately reflect a long-established performance practice of this spiritual. For example, melismas had been present in the very earliest transcriptions: In the 1872 publications, 12 of the 61 spirituals had a notated melisma, consisting usually of three or four pitches. ${ }^{10}$ The presence of these melismas - a clear link to folk performance of the spirituals - suggests that ornamentation was possibly more pervasive in performance than the transcriptions denote.

\section{Conclusion}

Do Seward's untutored transcriptions of a black folk tradition that had been altered by a white arranger have any usefulness or applicability some 125 years later? On what basis can we trust Seward's interpretations? Faced with evidence that the transcriptions contain substantial inaccuracies, should we reject them as useless because Seward's training and ideology so clearly prejudice his work? As William Noll points out, primary source materials are always in part products of the imagination. ${ }^{11}$ To learn something of value from historical transcriptions it is necessary, in Noll's words, to treat them "as a record of the ideologies and concerns of the researchers themselves as well as their time" (p. 173). Examining the ideologies underlying Seward's transcriptions reveals that these anthologies were not only musical records but political documents as well.

The jubilee songs were transcribed and sold for amateur home performance so that people could sing the spirituals in the manner of the Jubilee Singers. Seward's

${ }^{10}$ In Seward's first 1872 publication of Jubilee Songs: "I'll Hear the Trumpet Sound," "I've Just Come from the Fountain," "I'm a Trav'ling to the Grave," "I'm a-Rolling." In Seward's second 1872 edition: "Oh! Holy Lord," "He Arose," "These Are My Father's Children," "Reign, Oh! Reign," "I Ain’t Going to Die No More," "The General Roll," "Oh! Let Me Get Up," and "Oh! Sinner Man."

11 William Noll, "Selecting Partners: Questions of Personal Choice and Problems of History in Fieldwork and Its Interpretation," in Gregory Barz and Timothy Cooley, Shadows in the Field: New Perspectives for Fieldwork in Ethnomusicology, 163-188 (New York: Oxford University Press, 1997); this quotation is on p. 171. My questions are inspired by issues Noll raises. 
notes in the transcriptions and revisions to the scores indicate that form, rhythm, and the execution of cadences were likely to have been the most unfamiliar components of the spirituals for a northern white, middle-class audience. By assigning each spiritual a key and a time signature, Seward made these songs seem familiar at the same time that the form, rhythm, and words were exotic. Seward's assertion of their "correctness" reassured home users that any perceived anomalies ultimately conformed to a higher musical law and were thus within the ability of the average user. His remarks underscored the musical differences of the spirituals while proclaiming their commonalities with "cultivated" music. In this way, he put a "stamp of approval" on the spirituals, aligning them with the Victorian cultivated tradition instead of the stereotypical view of African music, which was associated with savagery and loss of sensory control.

Substantive revisions to text and music between editions were few, and seem to have been made only to the most popular spirituals. That mistakes such as incorrect or missing time signatures and incorrect note values persisted throughout 40 years of editions suggests a haphazard approach to publication, a highly constrained time schedule, financial restrictions, or more likely all of these. Although the transcriptions provide the merest skeletal framework for performance, they do shed light on interesting aspects of musical style and thus must be included in any attempt to reconstruct performance practice. Rather than malign them for what they fail to capture, we should treasure them for what they do contribute to the reconstruction of this important tradition of American music.

\section{PovZeTEK}

Ena izmed očitanih pasti oziroma zablod v okviru historične etnomuzikologije tiči v opiranju na analizo partitur, ko skušamo dognati, kako je ta glasba v resnici zvenela. To še posebej velja za zgodnje zapise ljudskih duhovnih pesmi v Ameriki, ki so jih često opravili ali amaterski glasbeniki ali pa njihovi šolani kolegi, ki pa niso bili doma $v$ ljudski glasbi. Theodora Sewarda, cerkvenega glasbenika, ki so ga leta 1872 najeli, da zapiše duhovne pesmi, ki in kakor so jih peli Fisk Jubilee Singers (Nashville, Tennessee), so sorodni znanstveniki kritizirali, da ni uspel reproducirati verne podobe zvoka duhovnih pesmi. Kljub njegovemu neuspehu pa podrobna analiza Sewardowih transkribcij kaže na stilistične zveze z ljudsko pesmijo in obenem nudi zanimive podatke o tem, kaj je bilo tisto, kar naj bi takrat, leta 1872, bela publika srednjega meščanskega razreda smatrala za originalno v tej glasbi. Zato Theodore Sewardove transkribcije rabijo kot prikaz njegovega šolanja (in domnev v glasbi v okviru tega šolanja) ter kot strateško izhodišče za oblikovanje mislenega koncepta glede duhovnih pesmi, s tem da so nakazane možnosti uporabe citiranih partitur kot vira koristnega etnografskega znanja. 